\title{
RANCANG BANGUN EARLY WARNING SYSTEM( EWS) PASOKAN IKAN TCT DI PROVINSI DKI JAKARTA
}

\author{
Design of Early Warning System (EWS) Supply Fish TCT in The Province of DKI Jakarta
}

\author{
Oleh: \\ Muhammad Luqman Triaji ${ }^{*}$, Sugeng Hari Wisudo², Mustaruddin ${ }^{2}$ \\ ${ }^{1}$ Mahasiswa Magister Program Studi Teknologi Perikanan Laut, Sekolah Pascasarjana IPB \\ ${ }_{2}^{2}$ Staf Pengajar Departemen Pemanfaatan Sumberdaya Perikanan, FPIK-IPB \\ *Korespondensi: ukaifunkai@gmail.com
}

\begin{abstract}
ABSTRAK
Manajemen dalam pasokan ikan merupakan hal penting dalam pencegahan IUU Fishing serta merupakan amanat Undang-undang Perikanan No. 45 Tahun 2009, dalam mengelola potensi sumber daya ikan Indonesia. Potensi sumber daya ikan Indonesia terbagi dalam 11 Wilayah Pengelolaan Perikanan Negara Repubik Indonesia (WPPNRI), salah satunya Provinsi DKI Jakarta yang berada di WPPNRI 712. Rancang bangun EWS pasokan ikan Tuna, Cakalang dan Tongkol (TCT) diharapkan dapat mengidentifikasikan kondisi supply dan demand dalam manajemen pasokan ikan. Hasil identifikasi tersebut sebagai forecasting patokan data dalam EWS pasokan ikan (TCT), sehingga kondisi pasokan ikan TCT dapat terpantau dalam keadaan shortage atau surplus. Penelitian ini merupakan metode kualitatif deskriptif dengan menggunakan model analisis forecasting antara lain eksponential smoothing seasonal. Berdasarkan hasil penelitian terhadap rancang bangun EWS pasokan TCT di DKI Jakarta, diketahui bahwa produksi TCT dari TPI, ditambah impor luar negeri dan domestik dalam keadaan shortage, hal ini terjadi karena kebutuhan adanya kebutuhan konsumsi TCT aktual susenas (3,23 kg/kapita/tahun) perkotaan DKI Jakarta sebesar 32.903,70 ton sedangkan kebutuhan ekspor sebesar 83.704,72 ton. Hasil forecasting satu tahun ke depan untuk tahun 2018 dibandingkan data collecting realtime antara forecasting demand dan realtime yang di supply atau dikonsumsi diketahui bahwa TCT (shortage), Tuna (surplus), Cakalang (shortage), dan Tongkol (shortage).
\end{abstract}

Kata kunci: Pasokan ikan, Tuna Cakalang Tongkol (TCT), Peramalan, Early Warning System (EWS), Supply dan Demand TCT, Sistem Pencatatan Ikan.

\begin{abstract}
Fish supply management is important in preventing IUU Fishing and is mandated by the Fishery Law no. 45 Year 2009, in managing the potential of Indonesian fish resources. The potential of Indonesian fish resources is divided into 11 State Fisheries Management Areas (WPPNRI), one of which is the Province of DKI Jakarta which is located in WPPNRI 712. EWS design of Tuna, Skipjack and Cob(TCT) supply can be trusted to identify supply and demand conditions in fish management. Design. The identification result is expected to be used as forecasting data as standard data in fish supply EWS (TCT), so that the condition of TCT fish supply can be monitored in a circumstances of shortage or surplus. This research is a descriptive qualitative research using analytical forecasting model such as seasonal exponential smoothing. Based on the results of the research on the design supply fish of TCT in DKI Jakarta, it is known that TCT production from TPI, plus foreign and domestic imports TCT consumption of Jakarta urban city (3.23 kg / capita / year) Jakarta amounted to 32,903.70 tons while export demand was 83,704,72 tons. Future forecasting results for 2018 compare
\end{abstract}


realtime data collection between demand forecast and realtime supplied or consumption of TCT inflation (shortage), Tuna (surplus), Skipjack (shortage, adn Cob (shortage).

Keywords: Fish Supply, Tuna, Skipjack, Cob, TCT, Forecasting, Early Warning System (EWS), Supply and Demand TCT, Fish Recording System.

\section{PENDAHULUAN}

Manajemen sistem rantai pasok dan sistem pencatatan merupakan amanah dari UU Perikanan No. 45 Tahun 2009 Pasal 46 ayat 1 dan 2, dalam mengelola potensi sumber daya ikan Indonesia. Potensi sumber daya ikan Indonesia terbaru dituangkan dalam Kepmen No. 47 Tahun 2016 menginformasikan potensi SDI di WPPNRI, antara lain : WPPNRI-571 (484.414 ton), WPPNRI-572 (1.228.601 ton), WPPNRI-573 (929.330 ton), WPPNRI-711 (1.143.341 ton), WPPNRI-712 (981.680 ton), WPPNRI-713 (1.026.599 ton), WPPNRI-714 (431.069 ton), WPPRI-715 (631.703 ton), WPPNRI-716 (478.765 ton), WPPNRI-717 (603.688 ton), WPPNRI-718 (1.992.730 ton).

Produk perikanan Tuna, Cakalang, dan Tongkol (TCT) merupakan produk yang memiliki potensi tinggi, sehingga perlu manajemen yang baik dalam mengelola potensi tersebut. Dalam kegiatan manajemen pasokan ikan dari produsen sampai ke konsumsi perlu ada inovasi baik dalam sistem logistik, dan sistem pencatatan ikan. Hal ini dilakukan agar supply produk perikanan (TCT) dapat memenuhi demand atau konsumsi produk TCT. Dalam prakteknya mungkin saja terjadi pasokan ikan (supply) lebih kecil dibanding kebutuhan konsumsi ikan (demand) hal tersebut tentunya dapat mengakibatkan shortage atau mungkin saja sebaliknya. Selain itu mungkin saja masih terjadi pasokan ikan TCT yang tidak tercatat oleh pemerintah atau tidak terlaporkan oleh pengusaha perikanan.

Provinsi DKI Jakarta merupakan salah satu sentralisasi penyerapan ikan nasional dari berbagai daerah, yang berada di WPPNRI 712. Hal ini didukung dengan adanya Pelabuhan Perikanan, tempat pelelangan ikan dan pendaratan ikan antara lain Muara Angke, dan Muara Baru. Berdasarkan Data Dinas Kelautan Pertanian dan Ketahanan Pangan Provinsi DKI Jakarta menyebutkan jumlah produksi perikanan tangkap lokal di provinsi DKI Jakarta pada tahun 2015 mencapai 289.214,10 ton dengan jumlah Angka Konsumsi Ikan (AKI) warganya 31,89 kg/kapita/tahun (Statistik DKPKP DKI, 2016). Selain itu di Provinsi DKI Jakarta terdapat berbagai industri yang bergerak dalam usaha perikanan, antara lain : industri pengolahan ikan, industri ekspor impor produk perikanan, dan industri lainnya yang tentunya dapat berpengaruh terhadap kebutuhan pasokan ikan yang masuk ke DKI Jakarta. Produk ikan di wilayah DKI Jakarta sebagian besar sangat tergantung pasokan dari luar DKI Jakarta (Raharjo, 2008). Besarnya kebutuhan dan ketergantungannya dari pasokan luar wilayah tersebut memerlukan pemantauan yang hati-hati agar tidak terjadi gejolak karena jumlah pasokan persediaan tidak sebanding dengan konsumsi masyarakat DKI Jakarta atau terjadi gangguan terhadap jalur pasokan.

Provinsi DKI Jakarta bukan tidak mungkin diterpa persoalan krisis pasokan ikan. Krisis pasokan ikan dapat terjadi dalam dua aspek, yakni: 1) Pasokan berlebih (surplus), dan 2) Pasokan langka atau kelangkaan pasokan (shortage). Tentunya dalam keadaan surplus dan shortage dapat mempengaruhi harga produk (Kusumawardani, 2012). Dalam mengantisipasi krisis pasokan ikan pasokan ikan di DKI Jakarta diperlukan Sistem Deteksi Dini (Early Warning System) guna menghindari terjadinya krisis pasokan ikan melalui langkah-langkah antisipatif yang cepat dan tepat. Hal ini didukung oleh UU 45/2009 tentang Perikanan, UU 18/2012 tentang Pangan dan PERMEN KP No.5/ 2014 tentang SLIN (Sistem Logistik Ikan Nasional).

Berdasarkan pemaparan di atas, perlu dilakukan suatu kajian untuk menganalisi kondisi eksisiting rantai pasok produk TCT serta kondisi pencatatan ikan di DKI Jakarta sebagai suatu rancang 
bangun EWS Pasokan ikan. Serta bertujuan untuk meramalkan (forecasting) permintaan atau demand sebagai pastokan Early Warning System (EWS) pasokan ikan (TCT) DKI Jakarta.

\section{METODE PENELITIAN}

Penelitian ini dilakukan di Provinsi DKI Jakarta antara lain : DKPKP Provinsi DKI Jakarta, TPI Muara Angke, TPI Muara Baru dan lokasi lainNya yang terkait dengan penelitian ini. Penelitian dilakukan selama tahun 2015 sampai tahun 2017. Metode dalam penelitian ini merupakan kualitatif deskriptif, dengan data kualitatif berupa data sekunder supply dan demand TCT dari DKPKP Provinsi DKI, BKIPM DKI Jakarta serta untuk kelengkapan data penelitian dilakukan observasi dan wawancara di lokasi penelitian secara purposive sampling. Data rancang bangun EWS pasokan ikan yang diperoleh merupakan data kualitatif yang dianalisis secara deskriptif. Merekayasa sistem rantai pasok bahan baku berbasis jaringan menjadi penting untuk meningkatkan hubungan pemasok dengan industri yang memberikan nilai tambah (Nunuk, 2007).

Berdasarkan data yang diperoleh data dalam penelitian ini merupakan data sekunder. Data sekunder yang diperoleh berupa data Angka Konsumsi Ikan (AKI), data ekspor impor, data produksi TPI dan data pendukung lainnya. Data yang diperoleh merupakan data runtun waktu yaitu data yang dikumpulkan, dicatat, atau diobservasi berdasarkan urutan waktu dengan tujuan adalah untuk menemukan bentuk data di masa lampau dan menggunakan pengatahuan ini untuk peramalan terhadap sifat-sifat data di masa yang akan datang (Rosadi, 2011). Data Perikanan dianalisis dengan melakukan metode analisis forecasting dengan model eksponential smoothing seasonal karena data sekunder TCT merupakan data musiman diuji dengan dua model eksponential smoothing yaitu seasonal smoothing additive dan multicative (Sihabuddin, 2017).

a) Pemulusan Eksponensial

b) Estimasi Trend

$$
L_{t}=\alpha Y_{t}+(1-\alpha)\left(L_{t-1}+T_{t-1}\right)
$$

$$
T_{t}=\beta\left(L_{t}-L_{t-1}\right)+(1-\beta) T_{t-1}
$$

c) Ramalan Periode $p$ ke depan

$$
\hat{Y}_{t+p}=L_{t}+p T_{t}
$$

dimana :

$\mathrm{L}_{\mathrm{t}} \quad=$ nilai pemulusan baru

- $\quad$ = konstanta pemulusan data $(0 \leq \alpha \leq 1)$

$\mathrm{Y}_{\mathrm{t}}=$ pengamatan baru atau nilai aktual pada periode $\mathrm{t}$

$\beta=$ konstanta pemulusan untuk estimasi trend $(0 \leq \beta \leq 1)$

$\mathrm{T}_{\mathrm{t}} \quad=$ estimasi trend

$p \quad$ = periode yang diramalkan ke depan

$\hat{\mathrm{Y}}_{\mathrm{t}+\mathrm{p}}=$ ramalan $p$ periode ke depan

Setelah diperoleh data demand produk TCT hasil forecasting, maka untuk menjawab tujuan penelitian terhadap Sehingga berdasarkan data kebutuhan pasokan ikan yang menjadi tolak ukur EWS pasokan ikan TCT adalah sebagai berikut :

- $\quad$ Surplus, terjadi jika :

$\sum$ Pasokan Ikan TCT $>\sum$ Forecasting Kebutuhan Ikan

- $\quad$ Shortage

$\sum$ Pasokan Ikan TCT $<\sum$ Forecasting Vol Kebutuhan Ikan 


\section{HASIL DAN PEMBAHASAN}

\section{Rantai Pasok Produk Perikanan DKI Jakarta}

Rantai pasok produk perikanan di Provinsi DKI Jakarta cukup kompleks hal ini diakibatkan karena adanya supply dan demand terhadap produk perikanan, sehingga mengakibatkan rantai distribusi dari produsen kepada konsumen sangat beraneka ragam. Kondisi tersebut juga dapat berpengaruh terhadap kegiatan pencatatan ikan di Provinsi DKI Jakarta, sehingga tidak memungkinkan masih terdapat data ikan yang masuk ke DKI Jakarta namun tidak tercatat. Provinsi DKI Jakarta pada tahun 2011- 2014 memiliki memilki 7 sentral tempat pendaratan ikan, antara lain : Kamal Muara, Muara Angke, Kali Baru, Muara Baru, Cilincing, Marunda dan Kali Adem. Namun semenjak tahun 2015 yang efektif digunakan hanya 3 lokasi yaitu Muara Angke, Kali Baru dan Muara Baru.

Pada tahun 2015 persentase ikan yang didaratkan di Muara Angke sebesar 27,64 persen, Kalibaru 0,84 persen dan Muara Baru 71,52 persen. Jumlah ikan yang didaratkan di Muara Angke dan Kali Baru lebih sedikit dibanding yang didaratkan di Muara Baru, karena kapasitas kapal yang berlabuh adalah kapal 1 - 30 GT sedangkan kapal penangkap ikan yang mendaratkan ikannya di Muara Baru memiliki kapasitas kapal lebih besar yaitu lebih dari 30 GT. Hasil produksi dapat dilihat pada Tabel 1.

Tabel 1. Produksi TPI di DKI Jakarta (dalam kilogram)

\begin{tabular}{lcccccccr}
\hline \multirow{2}{*}{ Tahun Kamal } & $\begin{array}{c}\text { Muara } \\
\text { Muara }\end{array}$ & Angke & Kali Baru & Muara Baru & Cilincing Marunda & $\begin{array}{c}\text { Kali } \\
\text { Adem }\end{array}$ & Jumlah \\
\hline 2011 & 271.090 & 20.624 .697 & 348.351 & 182.998 .863 & 121.945 & - & - & 204.364 .946 \\
2012 & 289.750 & 27.739 .863 & 352.161 & 215.608 .229 & 97.524 & - & - & 244.087 .527 \\
2013 & 278.589 & 28.318 .502 & 467.590 & 247.958 .912 & 97.364 & 121.417 & 225.954 & 277.468 .328 \\
2014 & - & 27.013 .991 & 1.271 .162 & 271.859 .801 & - & 124.172 & 218.051 & 300.487 .177 \\
2015 & - & 90.761 .867 & 2.743 .949 & 234.867 .150 & - & - & - & 328.372 .966 \\
\hline
\end{tabular}

Pasokan ikan laut yang masuk bukan hanya dari kapal ikan lokal namun terdapat kapal penangkap ikan dari daerah lain yang mendaratkan ikan di pelabuhan perikanan DKI Jakarta. Jumlah ikan jalur laut dan jalur darat yang masuk tempat pelalangan ikan DKI Jakarta dapat dilihat pada Tabel 2.

Tabel 2. Produksi TPI Berdasarkan Jalur Masuk di DKI Jakarta (dalam ton)

\begin{tabular}{cccccccccc}
\hline \multirow{2}{*}{ Tahun } & \multicolumn{3}{c}{ Ikan Jalur Laut } & \multicolumn{5}{c}{ Ikan Jalur Darat } & \multirow{2}{*}{ Total } \\
\cline { 2 - 9 } & Lokal & $\%$ & Luar & $\%$ & Lokal & $\%$ & Luar & $\%$ & \\
\hline 2011 & $120.359,04$ & 58,89 & $64.198,61$ & 31,41 & $1.028,32$ & 0,50 & $18.778,98$ & 9,19 & $204.364,95$ \\
2012 & $124.195,81$ & 50,88 & $99.652,96$ & 40,83 & $1.631,42$ & 0,67 & $18.607,34$ & 7,62 & $244.087,53$ \\
2013 & $133.197,01$ & 48,01 & $127.553,25$ & 45,97 & $1.849,63$ & 0,67 & $14.860,54$ & 5,36 & $277.460,43$ \\
2014 & $145.321,41$ & 48,36 & $142.889,57$ & 47,55 & 576,25 & 0,19 & $11.707,85$ & 3,90 & $300.495,08$ \\
2015 & $124.851,16$ & 38,02 & $147.650,60$ & 44,96 & 248,25 & 0,08 & $55.622,96$ & 16,94 & $328.372,97$ \\
\hline
\end{tabular}

Berdasarkan data Tabel 2, diketahui bahwa pasokan ikan yang masuk ke tempat pelelangan ikan didominasi oleh ikan jalur laut, dengan rata-rata pasokan ikan laut dari kapal perikanan lokal sebesar 48,83 persen. Sedangkan produksi ikan laut yang didaratkan oleh kapal perikanan dari luar DKI Jakarta rata-rata sebesar 42,15 persen. Sedangkan untuk produksi TCT yang masuk DKI Jakarta dapat dilihat pada Tabel 3. 
Tabel 3. Produksi Impor TCT di TPI DKI Jakarta (dalam ton)

\begin{tabular}{|c|c|c|c|c|c|c|}
\hline \multirow[t]{2}{*}{ Rincian } & \multirow[t]{2}{*}{$\begin{array}{l}\text { Produksi TPI } \\
\text { DKI Jakarta }\end{array}$} & \multicolumn{2}{|c|}{$\begin{array}{l}\text { Produksi Impor Domestik } \\
\text { ke TPI DKI Jakarta }\end{array}$} & \multicolumn{3}{|c|}{$\begin{array}{c}\text { Volume Produksi Ikan TCT di TPI } \\
\text { DKI Jakarta }\end{array}$} \\
\hline & & Jalur Laut & Jalur Darat & Tuna & Tongkol & Cakalang \\
\hline Total & $328.372,97$ & $147.650,60$ & $55.622,96$ & $18.996,83$ & $13.921,13$ & $37.095,30$ \\
\hline Persentase & $100,00 \%$ & $44,96 \%$ & $16,94 \%$ & $5,79 \%$ & $4,24 \%$ & $11,30 \%$ \\
\hline
\end{tabular}

Produk ekspor tuna yang tercatat oleh BKIPM KKP RI pada tahun 2015 sampai tahun 2017, terdapat lebih dari 30 negara tujuan ekspor dengan rata-rata ekspor per tahun sebesar 33.250,13 ton. Negara sepuluh besar sebagai tujuan ekspor adalah Thailand (14.207,62 ton), Spanyol (5.050,71 ton), Amerika Serikat (3.456,45 ton), Jepang (3.378,91 ton), Vietnam (1.550,17 ton), Italia (1.517,84 ton), Meksiko (837,90), Filipina (759,72 ton), Singapore (347,15 ton), Perancis (343,07 ton), sedangkan negara paling kecil yang menyerap ekspor Tuna dari DKI Jakarta antara lain : Qatar $(0,13$ ton), Kuwait $(0,58$ ton), Libanon ( 0,85 ton) dan Bahrain (1 ton).

Produk impor tuna pada tahun 2015 sampai tahun 2017, lima besar negara importir adalah Micronesia (1.389,65 ton), Cina (218,95), USA ( 81,18 ton), Ghana (48,23 ton), Malaysia (38,62 ton). Kondisi ekspor impor produk ikan Tuna, dapat dilihat pada Gambar 1.
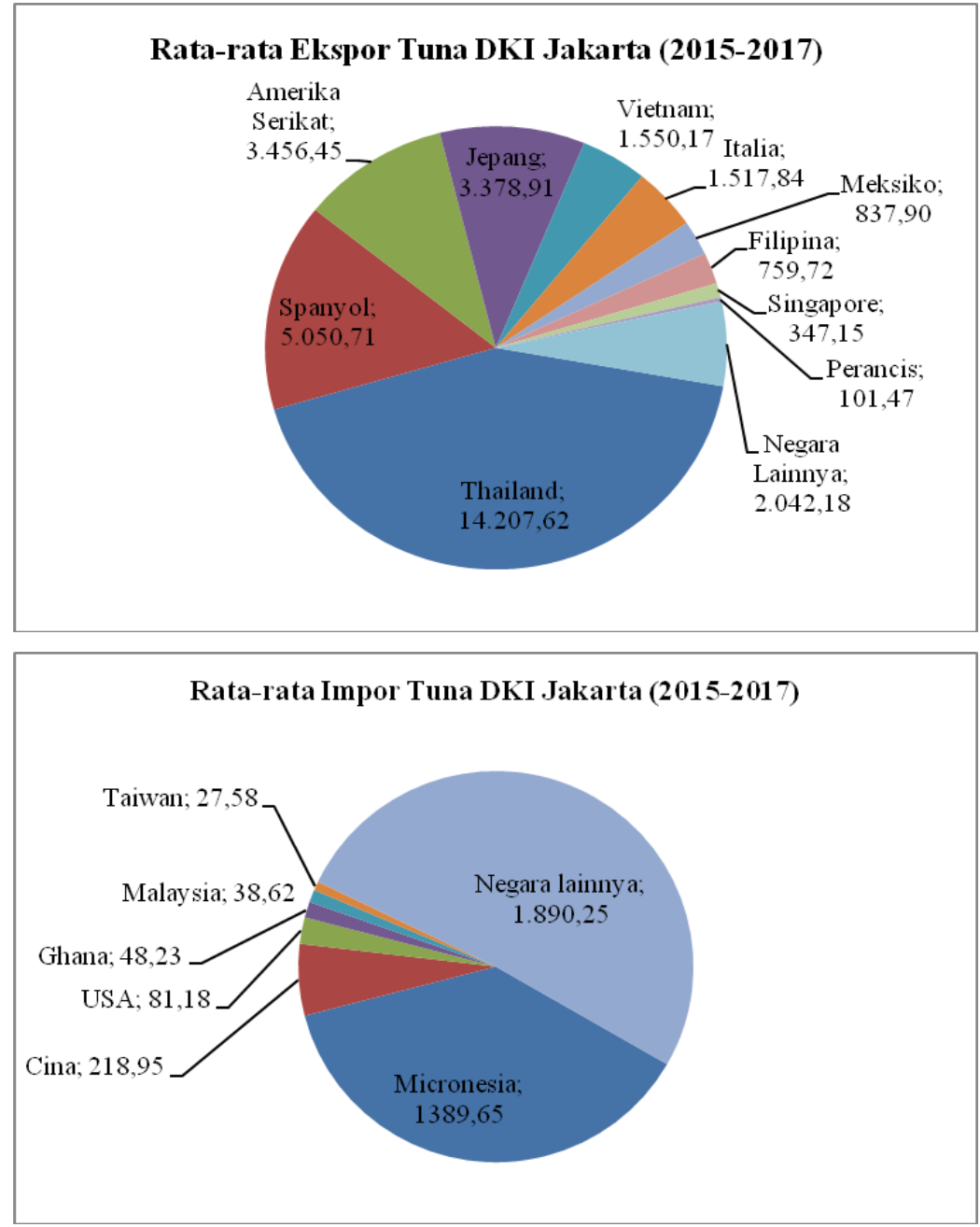

Gambar 1. Jumlah Rata-rata Eskpor Impor Tuna DKI Jakarta Tahun (2015-2017) 
Produk ekspor impor ikan Cakalang, berdasarkan data BKIPM KKP DKI Jakarta rata-rata ekspor per tahun dari tahun 2015-2017, untuk urutan 5 besar negara tujuan ekspor ikan Tongkol antara lain : Thailand (25.794,51 ton), Jepang (18.605,41 ton), Italy (6.507,68 ton), Filipina (3.725,67 ton) dan Spanyol (2.881,75 ton). DKI Jakarta menerima impor ikan Cakalang dari negara lain. Salah satu negara adalah negara Micronesia (1.213,01 ton), Spanyol (450 ton) dan Senegal (123,30 ton). Micronesia merupakan salah satu negara yang terletak di Samudera Pasifik yang mengekspor ikan Tuna dan Cakalang ke Indonesia. Hal ini dapat dilihat pada Gambar 2.
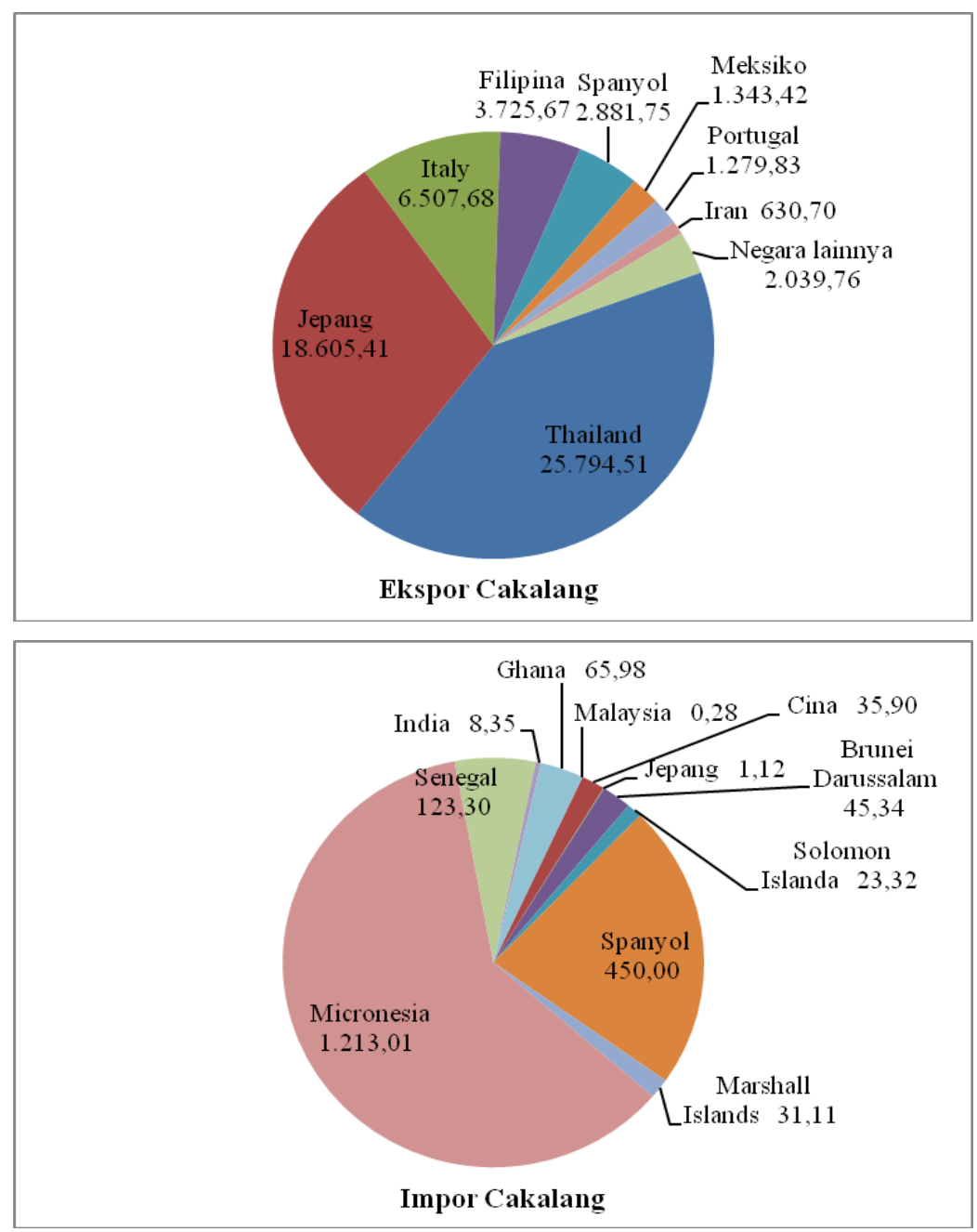

Gambar 2. Jumlah Rata-rata Eskpor Impor Ikan Cakalang DKI Jakarta Tahun (2015-2017)

Produk ekspor impor ikan Tongkol, berdasarkan data BKIPM KKP DKI Jakarta tahun 20152017. Urutan 5 besar negara tujuan ekspor ikan Tongkol rata-rata ekspor per tahun antara lain : Thailand (3.717 ton), Filipina (900 ton), Meksiko (300 ton), Spanyol (131 ton) dan Sri Langka (104,48 ton). Sedangkan negara yang mengimpor ikan Tongkol ke Indonesia pada tahun 2015 sampai dengan tahun 2017, hanya ada 2 negara yaitu : Cina (818 ton) dan Thailand (52 ton). Hal ini dapat dilihat pada gambar 3. 

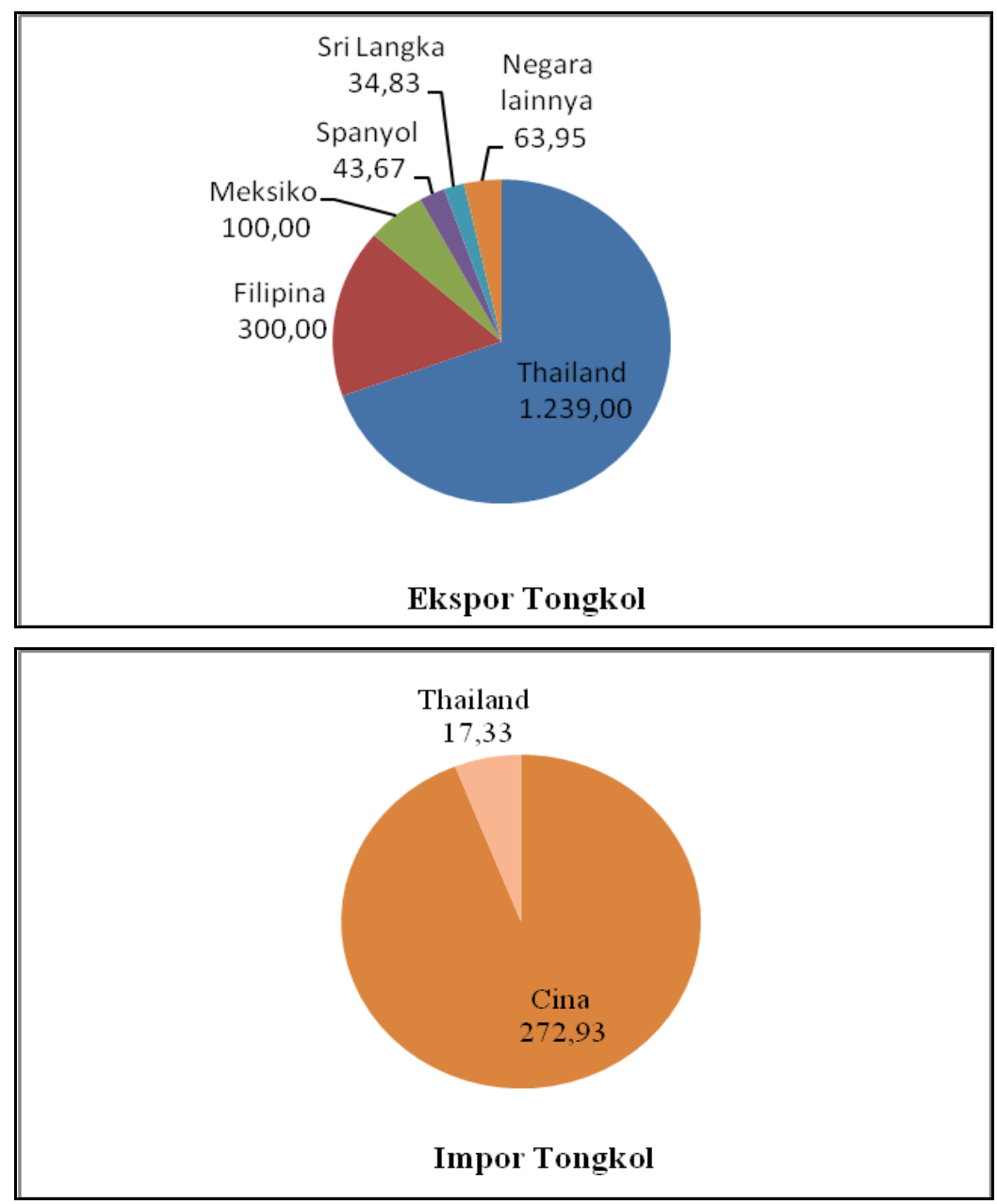

Gambar 3. Jumlah Rata-rata Eskpor Impor Ikan Tongkol DKI Jakarta Tahun (2015-2017)

Berdasarkan data dari Pusat Sertifikasi Mutu dan Keamanan Hasil Perikanan BKIPM-KKP, bahwa pada tahun 2014 di BKIPM Jakarta I Soekarno-Hatta terdaftar 56 UPI,dan 206 Certificate Regristation (CR). Sedangkan di BKIPM Jakarta II Tanjung Priok terdaftar 77 UPI dan 347 Certificate Regristation (CR). Provinsi DKI Jakarta, selain Unit Pengolahan Ikan (UPI) skala industri, terdapat UPI skala UKM atau industri rumah tangga. Berdasarkan data KKP 2010 terdapat 1.069 UPI.

Produk TCT umumnya masuk ke usaha retail dalam bentuk segar, beku, maupun olahan, seperti tuna loin, fillet tuna, cakalang asap, cue cakalang, cue tongkol, dan bentuk olahan lainnya. Data usaha retail DKI Jakarta dapat dilihat pada Tabel 4.

Tabel 4. Konsumen Horeka dan UMKM di DKI Jakarta 2015

\begin{tabular}{cccc}
\hline Hotel (2015) & $\begin{array}{c}\text { Restoran Besar } \\
\text { dan Menengah }\end{array}$ & $\begin{array}{c}\text { Restoran } \\
\text { mikro dan } \\
\text { kecil }\end{array}$ & $\begin{array}{c}\text { Pedagang Sayur Sembako } \\
\text { mikro dan kecil }\end{array}$ \\
\hline 440 & 3957 & 2171 & 261 \\
\hline
\end{tabular}

Sumber : diolah (2018) dari Dinas Pariwisata dan Kebudayaan,

Dinas Koperasi (2015), UMKM dan Perdagangan Provinsi DKI Jakarta (2015). 


\section{Konsumsi Perikanan DKI Jakarta}

Konsumsi perikanan DKI Jakarta tidak hanya dipengaruhi oleh konsumsi rumah tangga tetapi dipengaruhi juga kegiatan ekspor produk perikanan. Produk Tuna dan Cakalang yang diproduksi berdasarkan data TPI pada Tabel 2 dan Tabel 3, sebelumnya jumlah produksi Tuna 18.996,83 ton dan Cakalang 37.095,30 ton. Sedangkan produk ikan Tongkol produksi TPI DKI Jakarta sebesar 13.921,13 ton. Produksi TCT TPI DKI Jakarta ditambah impor luar negeri dan domestik secara keseluruhan tahun 2015 sebesar 73.586,32 ton, hal ini dapat dilihat pada Tabel 5.

Tabel 5. Konsumsi TCT DKI Jakarta Tahun 2015

\begin{tabular}{l|r}
\hline Jumlah Penduduk Tahun 2015 (ribu orang) & $10.177,90$ \\
\hline Produksi TPI+Impor Luar Negeri dan Domestik (ton/tahun) & $407.172,75$ \\
\hline AKI Tahun 2015 (kg/kapita/tahun) & 31,89 \\
\hline AKI TCT aktual Susenas 2012 rata2 perkotaan (kg/kaptita/tahun) & $\mathbf{3 , 2 3}$ \\
\hline Produksi TCT TPI+Impor Luar Negeri dan Domestik (ton/tahun) & $\mathbf{7 3 . 5 8 6 , 3 2}$ \\
\hline Konsumsi TCT aktual perkotaan DKI Jakarta & $\mathbf{3 2 . 9 0 3 , 7 0}$ \\
\hline Ekspor Luar+Domestik TCT 2015 DKI Jakarta (LPPMHP + BKIPM) & $\mathbf{8 3 . 7 0 4 , 7 2}$ \\
\hline Ekspor Luar + Domestik Tuna (ton/tahun) = 33.493,95 \\
\hline Ekspor Luar + Domestik Tongkol (ton/tahun) $=$ \\
\hline Ekspor Luar + Domestik Cakalang (ton/tahun) $=$ \\
\hline \multicolumn{2}{l}{ Sumber : Diolah (2018), Susenas BPS, Jakarta Dalam Angka (2017), BKIPM Jakarta (2018) }
\end{tabular}

Berdasarkan Tabel 5, bahwa produksi TCT dari TPI dan ditambah impor luar negeri dan domestik dalam keadaan shortage, hal ini terjadi karena kebutuhan adanya kebutuhan konsumsi TCT aktual susenas (3,23 kg/kapita/tahun) perkotaan DKI Jakarta sebesar 32.903,70 ton sedangkan kebutuhan ekspor sebesar 83.704,72 ton. Melihat kondisi di atas hal ini dapat disimpulkan bahwa :

- Terdapat kegiatan impor TCT, untuk memenuhi shortage TCT di DKI Jakarta

- Terdapat pasokan impor TCT yang tidak tercatat oleh pemerintah

- Perusahaan UPI yang memproduksi TCT tidak melaporkan sepenuhnya produksi TCT terhadap pemerintah

- Besar kemungkinan produk TCT yang tidak tercatat masuk melalui jalur darat dan langsung menuju UPI yang ada di DKI Jakarta.

\section{Kondisi Terkini Sistem Informasi Pencatatan di DKI Jakarta}

Pencatatan ikan merupakan sebuah sistem teknis dari kegiatan pendataan perikanan yang telah diamanatkan UU Perikanan No. 45 Tahun 2009 Pasal 46 ayat 1 dan 2, UU No.18 Tahun 2012 tentang Pangan, Permen KP No.5 Tahun 2014 tentang SLIN (Sistem Logistik Ikan Nasional).

Kegiatan pencatatan ikan baik kegiatan produksi (perikanan tangkap) dan kegiatan ekspor, pemerintah dalam sistem pencatatan ikan telah menyediakan SDM dan tools dalam proses pendataan perikanan. Penyediaan sistem dan tools pencatatan atau pendataan pasokan ikan, antara lain : pencatatan $\log$ book, Perizinan alat tangkap dan kapal, dan pemantauan penangkapan ikan menggunakan Vessel Monitoring System/VMS (Husni, 2016), serta Sertifikat Hasil Tangkapan Ikan (SHTI). Kondisi terkini alur pasokan ikan dan data perikanan dapat dilihat pada Gambar 4. 


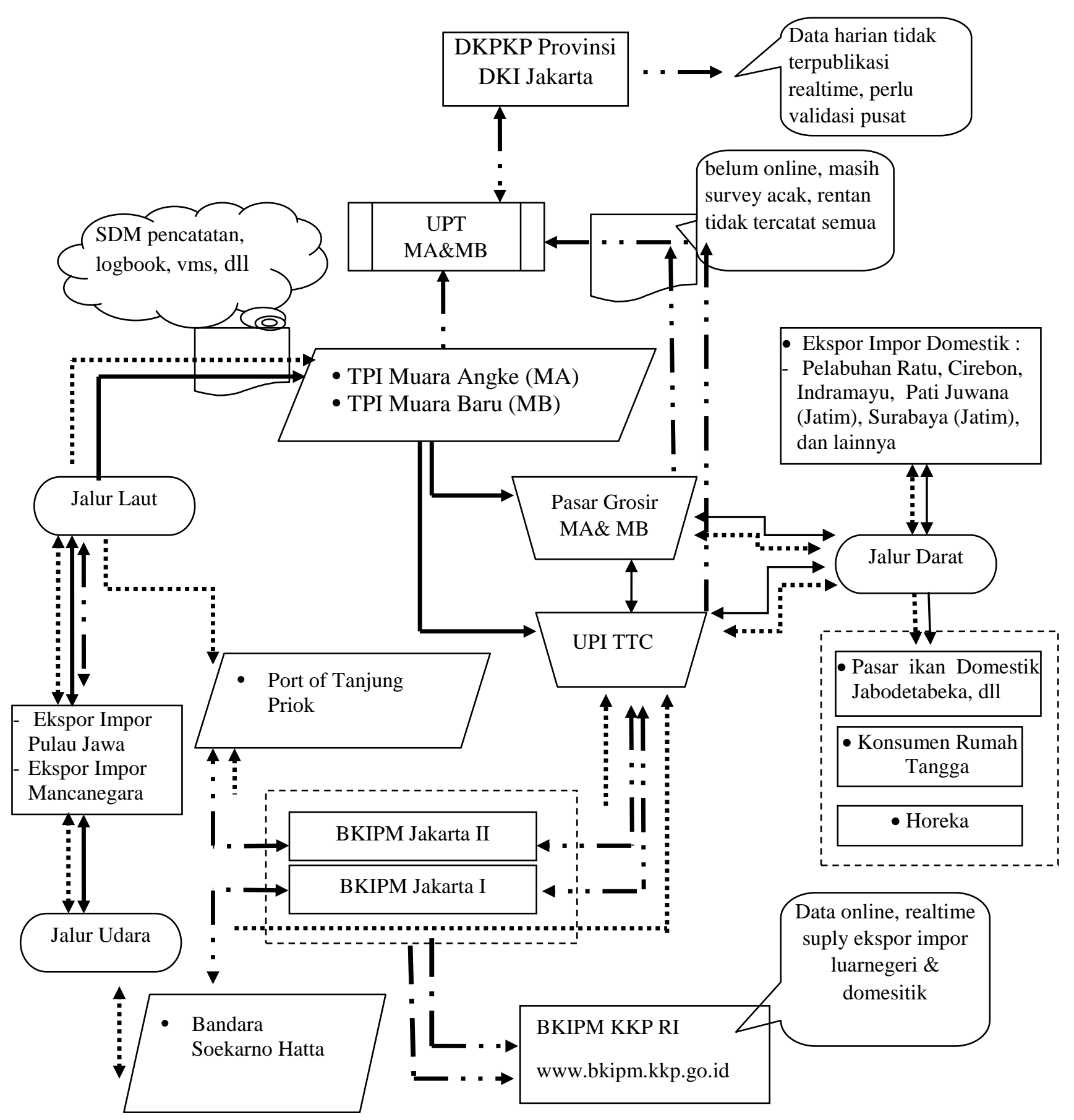

Keterangan :

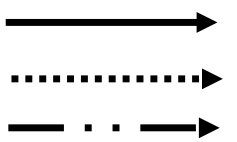

Produk lokal

Produk Ekspor Impor luar negeri dan domestik

Pendataan Produk Ekpor luar negeri dan domestik

Gambar 4. Alur Pasokan Produk Perikanan dan Data Passokan Ikan di DKI Jakarta

\section{Early Warning System (EWS) Pasokan Ikan di DKI Jakarta}

Kondisi EWS pasokan ikan TCT dalam penelitian berpegang pada kondisi TCT penawaran (supply) dan permintaan (demand). Penawaran (supply) TCT dalam tolak ukur EWS merupakan 
produk TCT yang sudah di supply atau dikonsumsi (consumption) untuk kebutuhan ekspor dan rumah tangga DKI Jakarta. Sedangkan permintaan (demand) TCT merupakan tolak ukur dari forecasting satu tahun ke depan dari kebutuhan konsumsi ekspor dan rumah tangga DKI Jakarta. Berdasarkan pembahasan sebelumnya terkait pasokan dan konsumsi ikan. Kondisi permintaan forecasting TCT DKI Jakarta untuk tahun 2018 berdasarkan hasil eksponential smoothing adalah sebagai berikut :

\section{Forecasting Tuna}

Kebutuhan atau permintaan ikan Tuna di DKI Jakarta untuk kebutuhan ekspor dan konsumsi rumah tangga pada tahun 2018. Model seasonal (musiman) dengan model Holt-winter Additive dan Multiclatipe dengan forecasting smothing holt-winter additive menunjukan pola yang lebih bagus dan mendekati kondisi. Hasil forecasting demand Tuna satu tahun ke depan (tahun 2018) dibandingkan dengan kondisi supply/consumption Tuna (pencatatan realtime Januari-Februari 2018), bahwa kondisi EWS Tuna DKI Jakarta pada bulan Januari 2018 dan Februari 2018 berada dalam keadaan Surplus, dapat diihat pada Tabel 5 dan Gambar 5.

Tabel 5. Kondisi EWS Pasokan Ikan Tuna DKI Jakarta

\begin{tabular}{cccccccc}
\hline Bulan & $\begin{array}{c}\text { Forecasting } \\
\text { Demand Tuna }\end{array}$ & $\begin{array}{c}\text { Real time } \\
\text { tuna } \\
\text { consumption }\end{array}$ & EWS & bulan & $\begin{array}{c}\text { Forecasting } \\
\text { Demand Tuna }\end{array}$ & $\begin{array}{c}\text { Real time } \\
\text { tuna } \\
\text { consumption }\end{array}$ & EWS \\
\hline Jan-18 & $3,383.2$ & 4291,87 & surplus & Jul-18 & $2,915.5$ & $O P$ & $O P$ \\
Feb-18 & $2,907.6$ & 3139,56 & surplus & Agu-18 & $3,627.4$ & $O P$ & $O P$ \\
Mar-18 & $2,941.7$ & $O P$ & $O P$ & Sep-18 & $3,822.6$ & $O P$ & $O P$ \\
Apr-18 & $2,531.8$ & $O P$ & $O P$ & Okt-18 & $3,593.0$ & $O P$ & $O P$ \\
Mei-18 & $2,974.4$ & $O P$ & $O P$ & Nov-18 & $4,101.0$ & $O P$ & $O P$ \\
Jun-18 & $3,084.7$ & $O P$ & $O P$ & Des-18 & $3,550.9$ & $O P$ & $O P$ \\
\hline
\end{tabular}

Sumber : diolah (2018), data realtime BKIPM

Keterangan : Surplus (konsumsi>demand), Shortage (konsumsi < demand), OP (on progres)

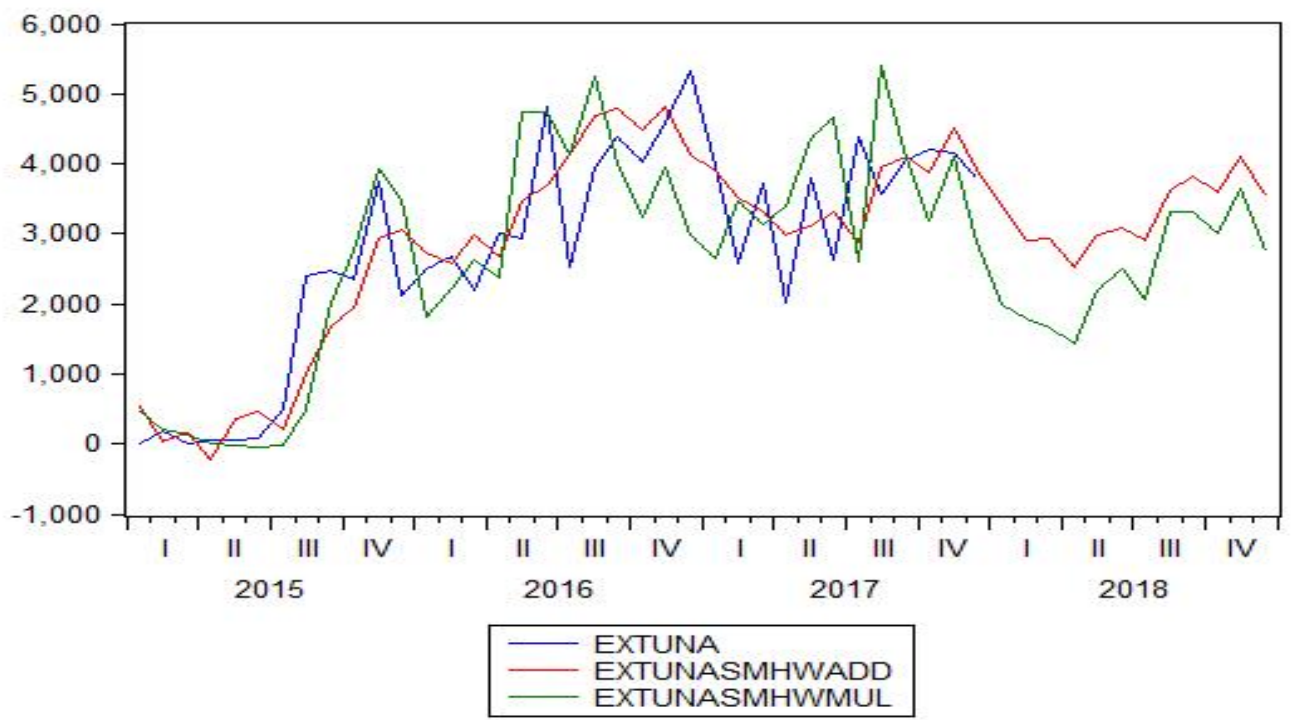

Gambar 5. Forecasting Tuna DKI Jakarta Tahun (2018) 


\section{Forecasting Cakalang}

Kebutuhan atau permintaan ikan Cakalang di DKI Jakarta untuk kebutuhan ekspor dan konsumsi rumah tangga pada tahun 2018. Hasil forecasting demand Cakalang satu tahun ke depan (tahun 2018) dibandingkan dengan kondisi supply/consumption Cakalang (pencatatan realtime Januari-Februari 2018), bahwa kondisi EWS Cakalang DKI Jakarta pada bulan Januari 2018 dan Februari 2018 berada dalam keadaan Shortage, dapat diihat pada Tabel 6 dan Gambar 6.

Tabel 6. Kondisi EWS Pasokan Ikan Cakaang DKI Jakarta

\begin{tabular}{cccccccc}
\hline Bulan & $\begin{array}{c}\text { Forecasting } \\
\text { Demand } \\
\text { Cakalang }\end{array}$ & $\begin{array}{c}\text { Real time } \\
\text { Consumption } \\
\text { Cakalang }\end{array}$ & EWS & bulan & $\begin{array}{c}\text { Forecasting } \\
\text { Demand } \\
\text { Cakalang }\end{array}$ & $\begin{array}{c}\text { Real time } \\
\text { Consumption } \\
\text { Cakalang }\end{array}$ & EWS \\
\hline Jan-18 & $6,064.57$ & 5256,24 & shortage & Jul-18 & $4,438.78$ & $O P$ & $O P$ \\
Feb-18 & $5,256.82$ & 4046,5 & shortage & Agu-18 & $7,153.13$ & $O P$ & $O P$ \\
Mar-18 & $5,326.22$ & $O P$ & $O P$ & Sep-18 & $8,010.33$ & $O P$ & $O P$ \\
Apr-18 & $6,065.87$ & $O P$ & $O P$ & Okt-18 & $9,204.38$ & $O P$ & $O P$ \\
Mei-18 & $5,320.08$ & $O P$ & $O P$ & Nov-18 & $8,148.58$ & $O P$ & $O P$ \\
Jun-18 & $5,132.73$ & $O P$ & $O P$ & Des-18 & $7,876.48$ & $O P$ & $O P$ \\
\hline
\end{tabular}

Sumber : diolah (2018), data realtime BKIPM

Keterangan : Surplus (konsumsi>demand),Shortage (konsumsi < demand), OP (on progres)

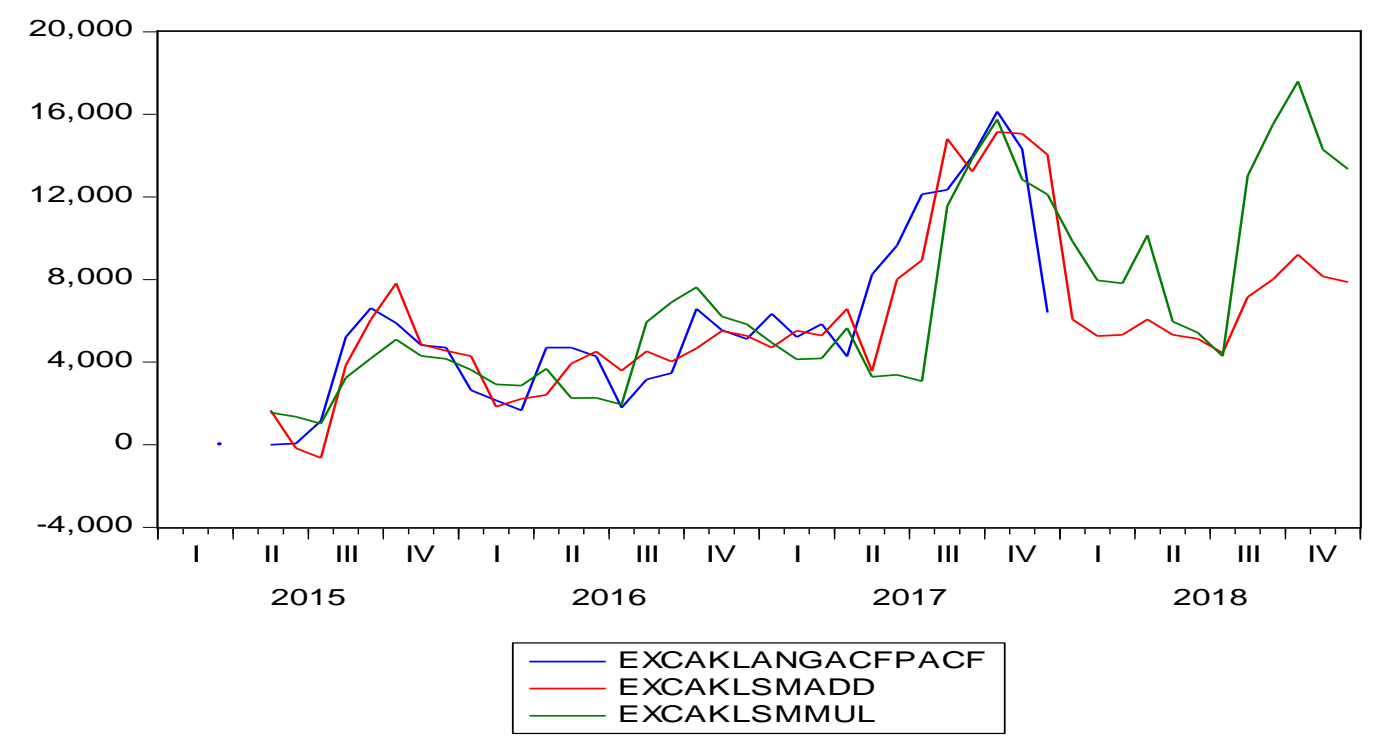

Gambar 6. Forecasting Cakalang DKI Jakarta Tahun (2018)

3. Forecasting Tongkol

Kebutuhan atau permintaan ikan Tongkol di DKI Jakarta untuk kebutuhan ekspor dan konsumsi rumah tangga pada tahun 2018. Model seasonal (musiman) dengan model Holt-winter Additive dan Multiclatipe menunjukan hasil forecasting demand Tongkol satu tahun ke depan (tahun 2018) dibandingkan dengan kondisi supply/consumption Tongkol (pencatatan realtime JanuariFebruari 2018), bahwa kondisi EWS Tongkol DKI Jakarta pada bulan Januari 2018 dan Februari 2018 berada dalam keadaan Shortage, dapat diihat pada Tabel 7 dan Gambar 7. 
Tabel 7. Kondisi EWS Pasokan Ikan Tongkol DKI Jakarta

\begin{tabular}{cccccccc}
\hline Bulan & $\begin{array}{c}\text { Forecasting } \\
\text { Demand } \\
\text { Tongkol }\end{array}$ & $\begin{array}{c}\text { Real time } \\
\text { Tongkol } \\
\text { consumption }\end{array}$ & EWS & Bulan & $\begin{array}{c}\text { Forecasting } \\
\text { Demand } \\
\text { Tongkol }\end{array}$ & $\begin{array}{c}\text { Real time } \\
\text { Tongkol } \\
\text { consumption }\end{array}$ & EWS \\
\hline Jan-18 & $1,076.6$ & 251,5 & shortage & Jul-18 & $1,265.9$ & OP & OP \\
Feb-18 & $1,077.3$ & 104,66 & shortage & Agu-18 & $1,183.5$ & OP & OP \\
Mar-18 & $1,077.2$ & $O P$ & OP & Sep-18 & $1,176.2$ & $O P$ & $O P$ \\
Apr-18 & $1,247.0$ & $O P$ & $O P$ & Okt-18 & $1,172.0$ & $O P$ & $O P$ \\
Mei-18 & $1,236.2$ & $O P$ & $O P$ & Nov-18 & $1,338.1$ & $O P$ & $O P$ \\
Jun-18 & $1,305.2$ & $O P$ & $O P$ & Des-18 & $1,537.0$ & $O P$ & $O P$ \\
\hline
\end{tabular}

Sumber : diolah (2018), data realtime BKIPM

Keterangan : Surplus (konsumsi>demand),Shortage (konsumsi < demand), OP (on progres)

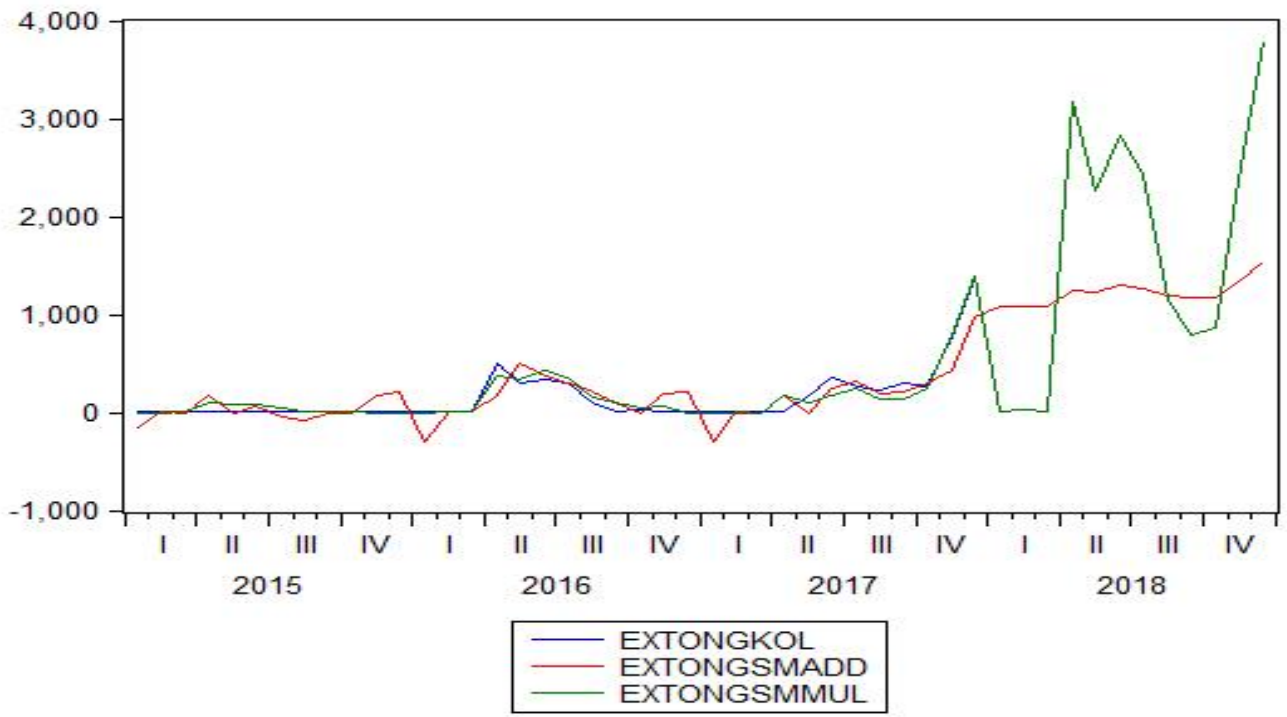

Gambar 7. Forecasting Tongkol DKI Jakarta Tahun (2018)

4. Forecasting TCT

Berdasarkan hasil forecasting sebelumnya terhadap masing-masing produk Tuna, Tongkol dan Cakalang, bahwa kondisi forecasting dan EWS dapat dilihat pada Tabel 8 dan Gambar 8.

Tabel 8 Kondisi EWS Pasokan Ikan Cakalang DKI Jakarta

\begin{tabular}{|c|c|c|c|c|c|c|c|}
\hline Bulan & $\begin{array}{c}\text { Forecasting } \\
\text { Demand } \\
\text { TCT } \\
\end{array}$ & $\begin{array}{c}\text { Real time } \\
\text { Consumption } \\
\text { TCT }\end{array}$ & EWS & bulan & $\begin{array}{c}\text { Forecasting } \\
\text { Demand } \\
\text { TCT } \\
\end{array}$ & $\begin{array}{l}\text { Real time } \\
\text { Consumption } \\
\text { TCT }\end{array}$ & EWS \\
\hline Jan-18 & $14,965.8$ & 9799,61 & shortage & Jul-18 & $17,494.2$ & $O P$ & $O P$ \\
\hline Feb-18 & $14,081.6$ & 7290,72 & shortage & Agu-18 & $20,133.7$ & $O P$ & $O P$ \\
\hline Mar-18 & $14,291.4$ & $O P$ & $O P$ & Sep-18 & $21,559.2$ & $O P$ & $O P$ \\
\hline Apr-18 & $14,673.5$ & $O P$ & $O P$ & Okt-18 & $22,974.9$ & $O P$ & $O P$ \\
\hline Mei-18 & $16,556.9$ & $O P$ & $O P$ & Nov-18 & $22,468.2$ & $O P$ & $O P$ \\
\hline Jun-18 & $17,206.4$ & $O P$ & $O P$ & Des-18 & $19,429.9$ & $O P$ & $O P$ \\
\hline
\end{tabular}

Sumber : diolah (2018), data realtime BKIPM

Keterangan : Surplus (konsumsi>demand),Shortage (konsumsi < demand), OP (on progres) 


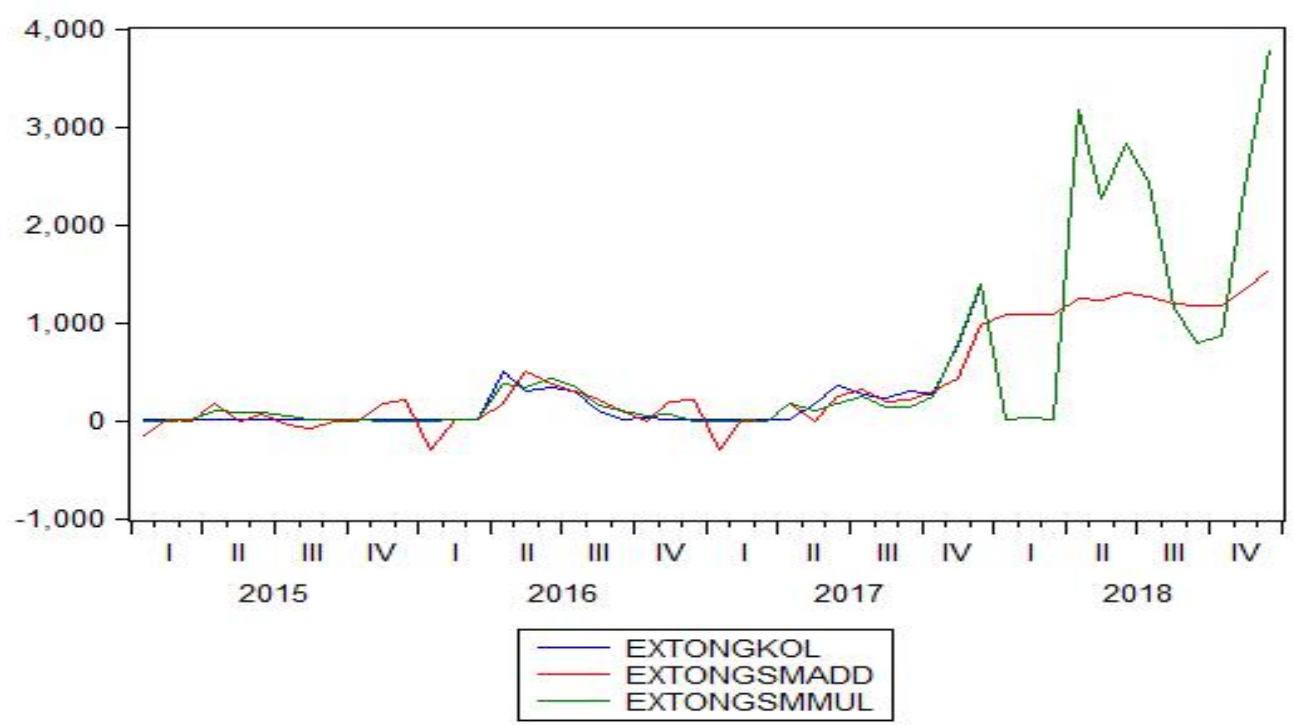

Gambar 8. Forecasting TCT DKI Jakarta Tahun (2018)

Hasil forecasting demand TCT satu tahun ke depan (tahun 2018) dibandingkan dengan kondisi supply/consumption TCT (pencatatan realtime Januari-Februari 2018), bahwa kondisi EWS TCT DKI Jakarta pada bulan Januari 2018 dan Februari 2018 berada dalam keadaan Shortage, dapat dilihat pada Tabel 8.

\section{KESIMPULAN DAN SARAN}

\section{Kesimpulan}

1. Kondisi Pasokan Ikan TCT, disimpulkan sebagai berikut :

- Pasokan ikan khususnya Tuna, Tongkol, dan Cakalang (TCT), masuk ke DKI Jakarta melalui jalur darat, laut dan udara. Jumlah produksi ikan DKI Jakarta sebagian besar dipasok atau diimpor dari domestik sebesar 61,90 persen dan 39,10 persen merupakan produksi lokal, dengan proporsi pasokan Tuna (5,79 \%), Tongkol (4,24\%) dan Cakalang $(11,30 \%)$.

- Kondisi rata-rata pasokan TCT mancanegara berdasarkan tiga besar importir dari tahun 2015 sampai tahun 2017 untuk masing produk antra lain : 1) Tuna : Micronesia (1.389,65 ton), Cina (218,95), dan USA (81,18 ton); 2) Tongkol : Cina (818 ton) dan Thailand (52 ton); 3) Cakalang : Thailand (25.794,51 ton), Jepang (18.605,41 ton),dan Italy $(6.507,68$ ton).

- Produksi TCT dari TPI dan ditambah impor luar negeri dan domestik dalam keadaan shortage, hal ini terjadi karena kebutuhan adanya kebutuhan konsumsi TCT aktual susenas (3,23 kg/kapita/tahun) perkotaan DKI Jakarta sebesar 32.903,70 ton sedangkan kebutuhan ekspor sebesar 83.704,72 ton.

2. Kondisi Pencatatan Pasokan Ikan TCT

Merujuk pada hasil pembahasan terhadap kondisi pasokan ikan supply TCT terhadap kebutuhan demand konsumsi domestik dan ekpor, dapat disimpulkan bahwa :

- Pencatatan produksi yang masuk melalui jalur darat kemungkinan besar banyak tidak tercatat, hal ini dapat dilihat pada kondisi shortage dimana jumlah ikan yang diekspor dari DKI Jakarta lebih besar dibanding ikan yang masuk ke DKI Jakarta. 
- Pasokan ikan ekspor dan impor melalui jalur laut Pelabuhan Tanjung Priouk dan jalur udara Bandara Soekarno Hatta sudah tercatat secara komputerisasi dan terpublikasi secara realtime.

3. Forecasting demand EWS TCT adalah sebagai berikut :

- Pasokan Tuna DKI Jakarta, pada bulan Januari 2018 dan Februari 2018 kondisi EWS adalah Surplus yaitu volume forecasting permintaan lebih kecil dibanding volume realtime yang di supply atau dikonsumsi.

- Pasokan Tongkol DKI Jakarta, pada bulan Januari 2018 dan Februari 2018 kondisi EWS adalah Shortage yaitu volume forecasting permintaan lebih besar dibanding volume realtime yang di supply atau dikonsumsi.

- Pasokan Cakalang DKI Jakarta, pada bulan Januari 2018 dan Februari 2018 kondisi EWS adalah Shortage yaitu volume forecasting permintaan lebih besar dibanding volume realtime yang di supply atau dikonsumsi.

- Pasokan TCT DKI Jakarta, pada bulan Januari 2018 dan Februari 2018 kondisi EWS adalah Shortage yaitu volume forecasting permintaan lebih besar dibanding volume realtime yang di supply atau dikonsumsi.

Saran

Perlu adanya peningkatan fasilitas pencatatan ikan dari Provinsi DKI Jakarta dalam hal ini DKPKP DKI Jakarta, karena data produksi dari TPI di DKI Jakarta penerbitannya masih belum realtime sehingga collecting data produksi lokal perlu validasi dari DKPKP DKI Jakarta.

\section{DAFTAR PUSTAKA}

Adiarni N, Jamaran I, Fauzi AM, Marimin, Machfud dan Sjarief Rl. 2007. Rekayasa Sistem Rantai Pasokan Bahan Baku Berbasis Jaringan Pada Agroindustri Farmasi. Jurnal Forum Pascasarjana. Vol.30 No.2 2007. Pp. 93-110.

Fitrian, Yuri. 2007. Perencaaan Arsitektur Enterprise di Perguruan Tinggi, Studi Kasus STMIK DARMAJAYA. Sekolah Pasca Sarjana, Institut Pertanian Bogor. [Tesis]

Heryadi Salya, Dida. 2006. Rekayasa Model Sistem Deteksi Dini Perniagaan Minyak Kelapa Sawit. Pasca Sarjana. Institut Pertanian Bogor. [Disertasi]

Husni EM, Andanawari MR, Triharjanto RH. 2016. Algoritma Peringatan Dini Pencurian Ikan Pada Data Automatic Identification System (AIS) Berbasis Terestrial dan Satelit. Jurnal Teknologi Dirgantara. Vol. 14 No.2 2016, pp. 81-90.

Jaap Schekkerman, B.Sc. 2004. “A Comparative Survey of Enterprise Architecture Framework”,

------, 2004. “Be Enterprising: What We can Learn from Other Countries”, 2004.

-----, 2007. Enterprise Architecture Tool Selection Guide Version 4.2, Institute For Enterprise Architecture Developments.

------, 2005.Trends in Enterprise Architecture 2005: How are Organizations Progressing? Copyright Institute For Enterprise Architecture Development

Kusumawardani IS, Gumila I, Rostini I. 2012. Analisis Surplus Konsumen dan Surplus Produsen Ikan Segar di Kota Bandung. Jurnal Perikanan dan Kelautan. Vol. 3 No. 4 2012, pp. 141-150.

Makridakis, S, Wheelright, S.C,Mcgee,V.E, 1999, Metoda dan Aplikasi Peramalan, Jakarta : Erlangga

Marc. 1998, Enterprise Architecture at Work, Modelling, Communication, and Analysis, Springer Verlag Berlin Heidelberg.

Munir. 2008. Kurikulum Berbasis Teknologi Informasi dan Komunikasi. Bandung: Alfabeta 
Open Group. 2007 The Open Group Architecture Framework (TOGAF) version 8.1.1, Enterprise Edition. Personal PDF Edition. Evaluation Copy.

Raharjo AWB, Elida T. 2008. Ketersedian Pangan Asal Ternak dan Ikan di DKI Jakarta Tahun 2007. Jurnal Ekonomi Bisnis. Vol. 13 No.2 2008, pp. 153-152.

Roger Sessions. 2007. ObjectWatch, Inc., Comparison of the Top Four Enterprises Architecture Methodologies.

Rodasi, Dedi. 2012. Ekonometrika \& Analisis Runtun Waktu Terapan dengan EViews. Yogyakarta: Graha Ilmu.

Sihabudin A, Rosadi D,dan Utami S. 2017. An Empirical Comparative Forecast Accuracy of Exponential Smoothing and Nonlinear Autoregresive Model on Six Major Rates. International Journal of Computer Science and Information Security (IJCSIS). Vol. 15 No.1 2017. Pp. 670672.

Windarta, Jaka. 2009. Pengembangan Sistem Peringatan Dini Banjir Kali Garang Semarang Dengan Teknologi Informasi Berbasis SMS dan WEB. Sekolah Pasca Sarjana. Institut Pertanian Bogor. [Tesis] 